\title{
TECTONIC SETTING AND SOURCES OF MAGMATISM RELATED TO THE SOUTHERN BRAZILIAN SHEAR BELT
}

\section{MARIA DE FÁTIMA BITENCOURT AND LAURO VALENTIM STOLL NARDI}

\begin{abstract}
The Neoproterozoic-Cambrian Brasiliano/Pan-African orogenic cycle is represented, in southern Brazil, by arc and collisional settings, with very expressive granitic magmatism. The post collisional stage, 650-580 Ma, is recorded by extensive magmatism along major transcurrent shear zones that compose the Southern Brazilian Shear Belt. The early post-collisional magmatism is high-K, calc alkaline, found along gently dipping shear zones; biotite-bearing granites and granodiorites are the most common rock types, often containing mafic microgranular enclaves. This is immediately followed by peraluminous two-mica leucogranites, emplaced either along flat lying or steeply dipping shear zones. The next magmatic manifestation has a shoshonitic affinity and is found either within the shear belt or far from deformation sites, piercing through cratonic areas. Shoshonitic rocks range from acid to basic, either as extrusive or plutonic terms. The latest magmatic event is a silica- saturated alkaline magmatism, occurring within or outside the shear belt. It is controlled by steeply dipping transcurrent structures, or discordantly intrusive in the previous types. Metaluminous biotite granites are widespread, with a coeval basic magmatism of mildly alkaline affinity. The shear belt acted as a conduit for magmas and also promoted decompression of shallower mantle levels, reactivating the sources of previous, calc-alkaline, pre-collisional magmatism. The role of previously modified mantle wedge in the generation of southern Brazilian postcollisional magmatism is here emphasized over the contribution of crustal melting processes.
\end{abstract}

Keywords: syntectonic magmatism; magma sources, Neoproterozoic magmatism, Southern Brazilian Shear Belt.

\section{INTRODUCTION}

Most granitoids from southern Brazil are related to the Brasiliano/Pan African Orogenic Cycle, which involved subduction of oceanic crust $(800-700 \mathrm{Ma})$ and collisional events among continents and magmatic arcs (ca. 700-500Ma), leading to the consolidation of Pangea supercontinent. This evolution follows the general pattern referred by several authors (e.g. Bonin et al. 1998), who emphasize that the orogenic Wilson cycle ends with a dominantly ensialic episode consisting of accretion of continental blocks or terranes. The collision strictu sensu is considered the initial major impact of two or more continental plates, characterized by major thrusts and high-pressure metamorphism (Liégeois 1998). The same author points out that this is followed by a post-collisional period marked by the activity of mega-shear zones and the rise of regional isotherms, with prominent production of a wide variety of magmas.

Magmatism in post-collisional setting has generated a large part of the granitic rock associations in southern Brazil. It encompasses high$\mathrm{K}$ calc-alkaline granitoids with minor dioritic components, plutonic and volcanic magmatism of shoshonitic affinity, plutonic and volcanic, silica-saturated magmatism of sodic-alkaline affinity, and peraluminous granite associations, as described by Liégeois (1998) and Harris et al. (1986), among other authors, for typical post-collisional settings, emphasizing also the relationship of post-collisional magmatism and the large horizontal movements along major shear zones.

Transcurrent shear zones whose activity extended from ca.650 to $580 \mathrm{Ma}$, during the so-called Dom Feliciano Event (Babinski et al. 1997) control a large part of the post-collisional magmatism in southern Brazil. A younger transcurrent event ( $c a .560 \mathrm{Ma}$ ), probably related to the Ribeira collision, controlled a new high-K calc-alkaline magmatism, represented by the Caçapava do Sul Granitic Complex and associated dioritic rocks, and probably affected the sources of silica-saturated alkaline magmas.

In this paper, the origin, diversity and tectonic control of postcollisional magmatism in southern Brazil is reviewed and discussed. A model is also proposed, attempting to explain the interplay between crustal-mantle sources and tectonics in magma generation.

GEOLOGICAL SETTING The oldest Precambrian areas in southern Brazil are composed of Early Proterozoic granulite associations, metamorphosed and deformed during the Transamazonic Cycle at $c a .2 .1 \mathrm{Ga}$. Calc-alkaline magmatism with arc-type signature was produced during the period between 800 and $700 \mathrm{Ma}$, and is represented mainly by metamorphosed tonalite associations, recognized in the western and eastern regions of the Sul-rio-grandense Shield (Silva Filho \& Soliani Jr. 1987, Babinski et al.1997, Kraemer 1995, Fragoso-Cesar et al. 1990, Silva et al. 1999). Their ages, indicated by whole rock $\mathrm{Rb}-\mathrm{Sr}$ and $\mathrm{U}-\mathrm{Pb}$ isotopic data in zircons, are about 710 and $780 \mathrm{Ma}$, respectively. According to geotectonic models previously proposed for the Neoproterozoic evolution of southern Brazil, these magmatic events represent more than one magmatic arc developed at different ages, or magmatic arc and back-arc basin magmatism (Fragoso-Cesar et al. 1990, Fernandes et al. 1992). Most

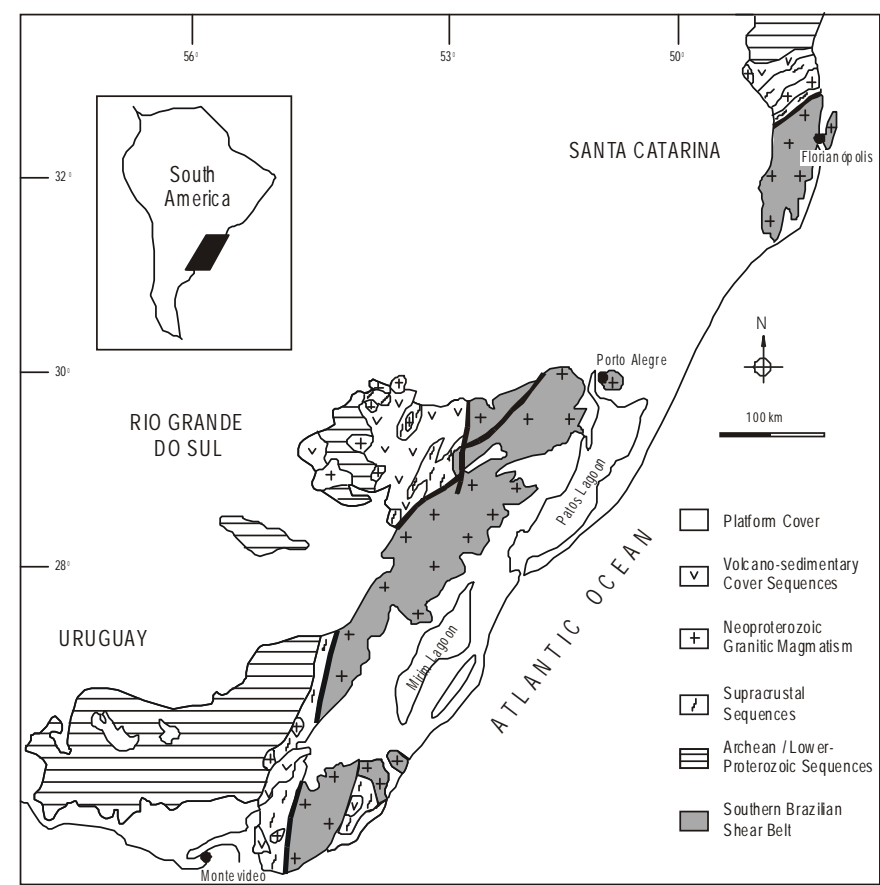

Figure 1 - Location and geological setting of Neoproterozoic granitic magmatism; modified from Bitencourt \& Nardi (1993).

authors admit, in either case, that the Brasiliano Cycle involved subduction of oceanic crust.

The magmatic arc magmatism was followed by widespread granitic magmatism (Fig. 1), partly associated with transcurrent structures, and partly in the zones preserved from major tectonic activity. Two major tectonic events are recorded in the Neoproterozoic terranes of southern Brazil, as recognized by several authors. Fernandes et al. (1992) described them as K1, characterized by deformation along flat-lying shear zones with E-W movement direction, under amphibolite facies metamorphic conditions, and K2, defined by sinistral strike-slip shear zones under low-grade metamorphic conditions. The K1 event is related to the collision between the Kalahari Craton and the Magmatic Arc I, whilst the K2 event is related to the closure of a marginal basin and collision between the Kalahari Craton-Magmatic Arc I and the Rio de La Plata Craton. Fragoso Cesar et al. (1990) and Basei \& Hawkeswoth (1993) related the first tectonic event with continentcontinent collision, and recognized the second one as constituted by large transcurrent shear zones. Bitencourt \& Nardi (1993) observed that most of this Neoproterozoic granitic magmatism is syn to posttrancurrence (K2), and that magmatic arc associations should be looked for among the pre-K1 orthogneissic associations. 

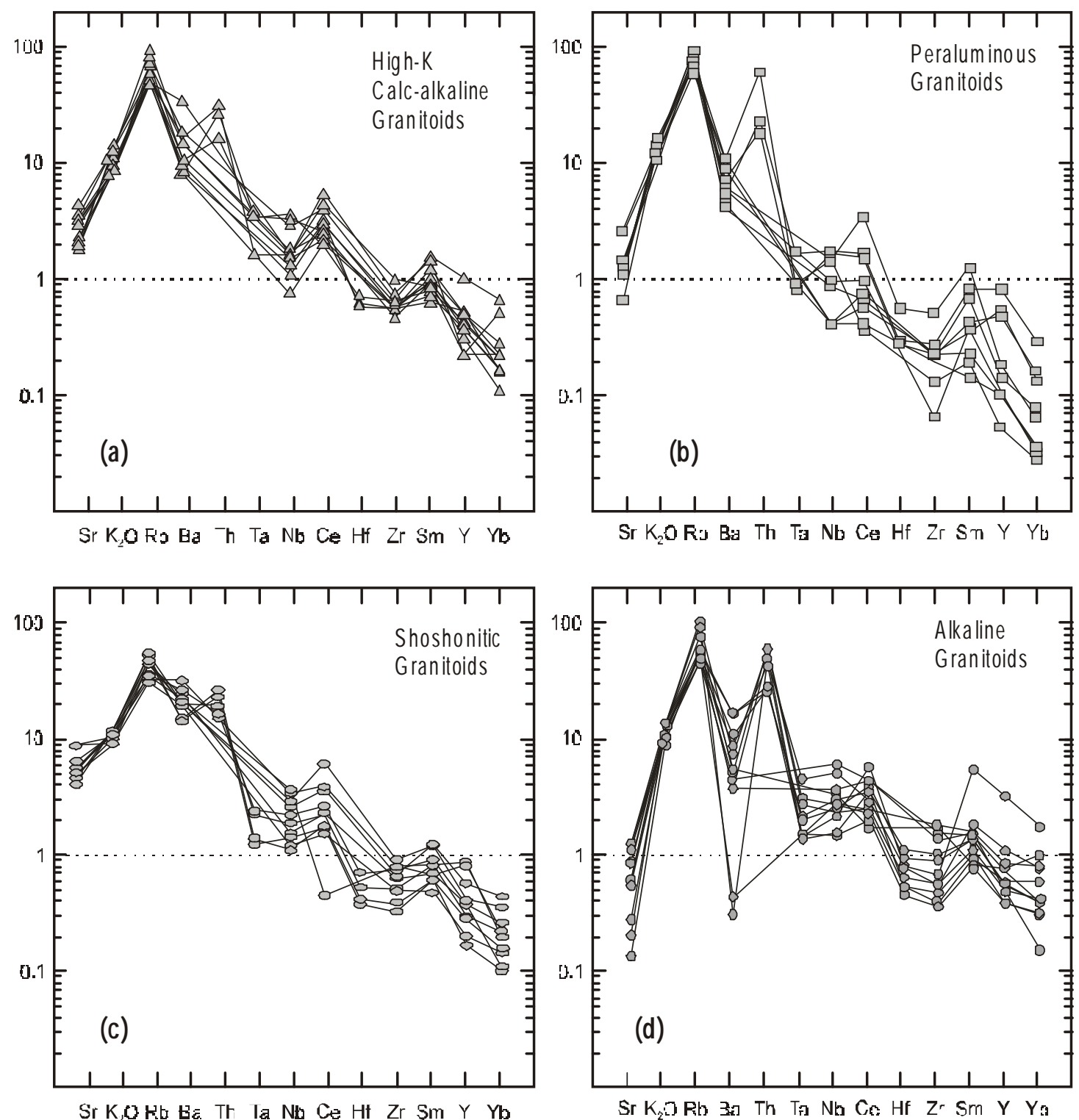

Figure 2 - Spiderdgrams of different post-collisional granitic associations normalized to ORG-granites (Pearce et al. 1984). Selected representative samples with about $70 \mathrm{wt} \% \mathrm{SiO}_{2}$.

STRUCTURAL OUTLINE The Southern Brazilian Shear Belt (SBSB - Bitencourt 1996) is a major crustal discontinuity formed in Neoproterozoic times, which was active in the period of $\mathrm{ca}$. 650 to 580 $\mathrm{Ma}$ ago, and comprises several km-wide, anastomosing shear zones of dominantly transcurrent kinematics. Most of the shear zones are steep dipping, with strikes ranging from NS to N60E, of either dextral or sinistral sense of displacement. Available data point to greenschist to low-amphibolite facies conditions in these shear zones. A general tendency for sinistral displacement is observed in the NS branches, while the NE branches are either dextral, as in the Major Gercino Shear Zone, Santa Catarina (Bitencourt \& Nardi 1993) or sinistral, as in the Dorsal de Canguçu Shear Zone, Rio Grande do Sul (Fernandes et al. 1992). A compatible shear regime is registered in gently dipping, NE-E striking shear zones. The early, high-K calc-alkaline granitic magmatism of $c a$. 650-630 Ma seems to have been mainly controlled by these flat-lying shear zones, as observed in Santa Catarina and in Rio Grande do Sul. Along major shear zones, syntectonic peraluminous granites are described, ranging from $\mathrm{ca}$. 630-617 Ma, and are followed by shoshonitic ( $\mathrm{ca}$. $600 \mathrm{Ma}$ ) and younger alkaline associations.

The intensity of foliation development in granitoids of this period is quite variable. They range from strongly foliated intrusions, whose early primary fabrics grade into subsolidus, mylonitic ones and may extend into low-temperature solid-state features, to late-transcurrence intrusions, with poorly developed fabrics and quite localized, metersized high-strain zones. However, even these late intrusions do show some type of relationship to transcurrence, either as scattered zones of channeled flow, or in the NE-elongated geometry of the intrusions. An additional cause for the poor development of mylonitic foliation is magmatic intrusion in low-strain zones within the shear belt.

The ubiquitous NE trends of granitoids within the SBSB, as well as their steep-dipping foliation, call for some type of genetic link between magmatism and crustal-shearing, unless it can be proved that these lineaments are much older and have exerted only a geometric control as previous zones of weakness. On the other hand, the common syntectonic character of most of these granitoids, abundantly described in local literature, reinforce the first hypothesis.

\section{PETROGRAPHIC AND GEOCHEMICAL CHARACTERIS-}

TICS The high-K calc-alkaline magmatism is dominated by biotite granites and granodiorites with quartz-dioritic to dioritic mafic enclaves, constituting very large bodies, sometimes with areas over a thousand square kilometers. Textures are commonly hypidiomorphic, heterogranular to porphyritic, often marked by centimeter-sized, euhedral to subhedral feldspar grains dispersed in a medium to coarsegrained matrix. Mafic microgranular enclaves interpreted as produced by co-mingling, are widespread.

The high-K calc-alkaline post-collisional magmatism in Southern 
Brazil is well exemplified by the Quatro Ilhas granitoids (Bitencourt \& Nardi 1993), Quitéria granites (Koester 1995), and Viamão and Arroio Moinho granites (Philipp 1998). These granite associations are dominated by metaluminous to slightly peraluminous rocks, with LILE-enriched character and moderate Sr contents (Fig. 2a).

Peraluminous leucogranites, mainly equigranular to heterogranular, with subordinate porphyritic varieties, form elongated circumscribed intrusions within shear zones. Xenoliths of orthogneisses and of high$\mathrm{K}$ calc-alkaline granitoids are ubiquitous. Muscovite, with variable amounts of biotite, tourmaline and garnet are the main mineral phases. Intense solid-state foliation development is commonly reported for these intrusions, concordantly overprinting early magmatic fabrics, which are preserved in low-strain zones. Arroio Francisquinho granites (Koester 1995), the Cordlheira Intrusive Suite (Nardi \& Frantz 1995) and Mariscal granite (Bitencourt \& Nardi 1993) exemplify this sort of granite association in southern Brazil.

Peraluminous granites show relatively low amounts of normative corindon, and their trace-element patterns (Fig. 2b) are similar to those of crustal derived granites. Their genesis is attributed to the partial melt of orthogneisses during the transcurrence event, as suggested by Nardi \& Frantz (1995).

Shoshonitic magmatism encompasses granodiorites and monzogranites which are dominant in the plutonic associations found within shear zones, whilst basic to acid volcanic associations predominate towards cratonic areas. In both settings, coeval mafic liquids are commonly found in association with granitic magmatism, either as abundant microgranular enclaves or as synplutonic dykes. Granitic rocks are mainly porphyritic to heterogranular, with hypidiomorphic textures, and contain diopside, amphibole and biotite as the main mafic minerals. The Lavras do Sul Shoshonitic Association (Lima \& Nardi 1998), Estaleiro Granitic Complex (Bitencourt \& Nardi 1993) and Monte Bonito granite (Philipp 1998) are typical examples of post-collisional shoshonitic magmatism in Southern Brazil.

Granitic rocks of shoshonitic affinity associated to the SBSB are mostly metaluminous. Sr and other LILE, as well as LREE are quite enriched (Fig. 2c), whilst HFS and HRE element contents are lower inside the shear belt, where they show trace element patterns closer to those of high-K calc-alkaline magmatism. The origin of shoshonitic granitoids in southern Brazil has been ascribed to the evolution of basalts derived from EM1 type mantle sources, through fractional crystallization processes, involving mainly clinopyroxene and plagioclase (Lima \& Nardi 1998).

Assuming the post-collisional magmatism as restricted to the 650580 Ma age interval, the silica-saturated alkaline magmatism inside the shear belt is mostly represented by biotite syenogranites and monzogranites. Piercing through cratonic areas, alkali-feldspar granites with associated syenitic terms are found. Coeval mafic magmatism is voluminous, and comprehends basaltic to dioritic terms displaying several geological features, such as minor dioritic intrusions, mafic dyke swarms, composite dykes, and mafic microgranular enclaves of several dimensions. Basic to acid volcanic rocks are exposed in several plateaus located in the areas more preserved from deformation. Within the shear belt, intrusive terms are typically medium to coarse-grained, heterogranular biotite granites. Metaluminous granites are dominant in the SBSB alkaline magmatism; peralkaline terms are also found as granitic intrusions, rhyolite dykes, and volcanic rocks, and share the characteristics of being emplaced far from deformational sites. Figure $2 \mathrm{~d}$ shows the similarity of metaluminous alkaline granites with calc-alkaline and shoshonitic patterns, although they are slightly enriched in HFS elements, and relatively depleted in Sr. Basic rocks of mildly alkaline affinity occur as lava, dikes or mafic microgranular enclaves in granitic intrusions (Nardi \& Bitencourt 1993, Wildner et al. 1999). The generation of more differentiated alkaline rocks, including metaluminous granites, involves mainly mineral-fractionation processes, with minor contribution of crustal components (Wildner at al. 1999, Nardi \& Bonin 1991).

\section{PETROGENESIS AND EVOLUTION OF MAGMATISM IN}

\section{THE SBSB Although the close spatial and temporal relationships} between granitoids and tectonics have been recognized by several authors in the last decades, few of them have suggested a direct connection between these two phenomena, as a cause-effect relationship. The model here developed is in agreement with some of the ideas outlined in Watson (1984), Hutton \& Reavy (1992) and D'Lemos et al. (1992) relative to the interplay between magmatism and tectonics.

The SBSB is envisaged as a lithospheric-scale discontinuity active in a post-collisional setting, during the late stages of Brasiliano Cycle (ca. 650-580 Ma), whose establishment has activated previously subduction-modified mantle sources and promoted crustal melting. Additionally, it has provided the conduits for the ascent and emplacement of these melts. The widespread occurrence of coeval mafic magmas with most of the granitic magmatism, besides elevating regional geothermal gradients, attests to the importance of mantle sources, as opposed to models based mainly upon crustal-derived magmatism. Additionally, the evolution of mafic magmatism, at least from shoshonitic to alkaline ones, following that observed for granitic terms, points to a process involving the parallel evolution of mantle sources interacting with crustal ones. It is here suggested that this process, rather than a progressively higher degree of crustal contamination, is responsible for the observed evolutionary trend in the post-collisional granitic magmatism. The role of crustal melting is clear in the generation of peraluminous leucogranites, and also as a secondary component in the high-K calc-alkaline magmatism diversity, but it does not seem to be determinative, either of major evolutionary compositional trends or as an important component of the subsequent shoshonitic and alkaline magmatism.

The possible effects of crustal-scale shearing in magma genesis are not restricted to lower-crust partial melting; it is also important in facilitating mantle partial melting through adiabatic decompression, leading to volatile concentration in the previously metassomatized lithospheric mantle. Such mechanism leads to an effective participation of subduction-modified sources, which is in turn responsible for the observed similarity of evolutionary trends in post-collisional and magmatic-arc environments, as previously pointed out by Harris et al. (1986).

The enhanced volatile activity within the shear belt promotes larger degrees of partial melting in the mantle or crustal source, leading to different compositional patterns of magmatism inside and outside this discontinuity. This explains the observed difference in compositional patterns of the shoshonitic and alkaline magmatism inside and outside the shear belt, as well as the relative abundance of crustal-derived liquids within these zones. The lithological diversity of granitic rocks in SBSB is partially caused by the variable degrees of interaction of coeval mafic and granitic magmas.

The larger crustal contribution observed in the early stages of the SBSB development, as in the generation of peraluminous and high-K calc-alkaline melts, can be related to the volatile concentration favored by increased crustal porosity due to the establishment of the discontinuity, and to the availability of hydrous mineral phases in the host rocks. As the tectonic activity tends to decrease, due to the progressive waning of stress field, porosity is also decreased, as well as the availability of hydrous phases, due to progressive dehydration of sources.

It is thus suggested that the post-collisional magmatism in Southern Brazil (650-580Ma) has been mainly controlled by a major lithospheric-scale discontinuity, which has influenced not only its ascent and emplacement, but has also reactivated previously subduction-affected mantle sources and promoted crustal melting.

Acknowledgements To CNPq, Fapergs and PRONEX for financial support and two anonymous referees of RBG for the critical review of the manuscript. 


\section{References}

Babinski M., Chemale Jr. F., Van Schmus W.R., Hartmann L.A., Silva L.C. 1997. U-Pb and Sm-Nd geochronology of the Neoproterozoic granitic-gneissic Dom Feliciano Belt, Southern Brazil. J. South Am. Earth Sci., 10:263-274.

Basei M.A.S. and Hawkesworth C. 1993. O magmatismo do Cinturão Dom Feliciano (SC) e sua importância no estabelecimento das principais descontinuidades crustais da região sul-brasileira. In: Simp. Intern. del Neoproterozoico-Cambrico de la Cuenca del Plata, 1, La Paloma-Minas, Uruguay, 1993. Resumenes Extensos... Montevideo. Dinamige-Fac. Agron., 2:41.

Bitencourt M.F. 1996. Granitóides sintectônicos da região de Porto Belo, SC: uma abordagem petrológica e estrutural do magmatismo em zonas de cisalhamento. Porto Alegre. 310 p. PhD Thesis, Instituto de Geociências, Universidade Federal do Rio Alegre. $310 \mathrm{p}$.
Grande do Sul

Bitencourt M.F. and Nardi L.V.S. 1993. Late- to post-collisional Brasiliano Magmatism in Southernmost Brazil. An. Acad. Bras. Ci. 65:3-16.

Bonin B., Azzouni-Sekkal A., Bussy F., Ferrag S. 1998. Alkali-calcic and alkaline postorogenic (PO) granite magmatism: petrologic constraints and geodynamic settings.

D'Lemos R.S., Brown M., Strachan R.A. 1992. Granite magma generation, ascent and emplacement within a transpressional orogen. J. Geol. Soc. London, 149:487-490.

Fernandes L.A.D., Tommasi A., Porcher C.C. 1992. Deformation patterns in the souther Brazilian branch of the Dom Feliciano Belt: A reappraisal. J. South Am. Earth Sci. 5:77-96.

Fragoso Cesar A.R.S., Machado R., Monteiro R.L., Sallet R. 1990. Nappes e estruturas correlatas do Cinturão Dom Feliciano no Escudo Uruguaio-Sul-rio-grandense: uma introdução ao problema. Acta Geol. Leop., 30:75-92.

Harris N.B.W., Pearce J.A., Tindle A.G. 1986. Geochemical characteristics of collision-zone magmatism. In: Coward M.P. \& Ries A.C. (eds) 1986. Collision Tectonics. Geol. Soc. Am. Spec. Publ. n ${ }^{\circ} 19$, p.67-81.

Hutton D.H.W. and Reavy R.J. 1992. Strike-slip tectonics and granite petrogenesis. Tectonics, 11:960-967.

Koester E. 1995. Evolução geológica do magmatismo sintectônico à zona de cisalhamento transcorrent Dorsal de Canguçu, região de Encruzilhada do Sul, RS. Porto Alegre, 122 p. MSc Thesis, Instituto de Geociências. Universidade Federal do Rio Grande do Sul, Brazil

Kraemer G. 1995. Evolução magmática e tectônica da Suíte Ortometamórfica Ibicuí, re gião de Lavras do Sul (RS). Porto Alegre, 99p. MSc Thesis, Instituto de Geociências-Universidade Federal do Rio Grande do Sul, Brazil.
Liégeois J.P. 1998. Some words on the post-collisional magmatism. Preface to Special Edition on Post-Collisional Magmatism. Lithos, 45 :xv-xvii..

Lima E.F. and Nardi,L.V.S 1998. The Lavras do Sul Shoshonitic Association: implication for the origin and evolution of Neoproterozoic shoshonitic magmatism in southernmost Brazil. J. South Am. Earth Sci. 11:67-77.

Nardi L.V.S. and Bitencourt M.F. 1993. Tholeiitic, late-orogenic basic magmatism in the region of Porto Belo, Southern Brazil. In: Semana de Geoq., 9, e Congr. Geoq. Países de Língua Portuguesa, 2, Porto, 1993. Memórias... Porto, Univ. do PortolFac. de Ciências\Museu e Lab. Mineral. e Geol., 3:131-135.

Nardi L.V.S. and Bonin B. 1991. Post-orogenic and non-orogenic alkaline granite associations: the Saibro Intrusive Suite, Southern Brasil - A case study. Chem. Geol., 92:197-211.

Nardi L.V.S. and Frantz J.C. 1995. The Cordilheira Intrusive Suite: late-precambrian peraluminous granitoids from south Brazil. J. South Am. Earth Sci., 8:55-63.

Pearce J.A., Harris N.B.W., Tindle A.G. 1984. Trace element discrimination diagrams for the tectonic interpretation of granitic rocks. J. Petrol., 25:956-983.

Phillip R. 1998. A evolução geológica e tectônica do Batólito Pelotas no Rio Grande do Sul. São Paulo, 255p. PhD Thesis, Instituto de Geociências, Universidade de São Paulo.

Silva F $F^{\circ}$ B.C. and Soliani Jr. E. 1987. Origem e evolução dos Gnaisses Cambaí: exemplo de estudo integrado de análise estrutural, petroquímica e geocronologia.In: Simp. SulBras. Geol., 3, Curitiba, 1987. Atas... Curitiba, SBG, 1:127-145.

Silva L.C., Hartmann L.A., McNaughton N.J., Fletcher I.R. 1999. SHRIMP U/Pb zircon timing of Neoproterozoic granitic magmatism and deformation in the Pelotas Batholith in Southernmost Brazil. Intern. Geol. Rev., 41:531-551.

Watson J. 1984. The ending of the Caledonian orogeny in Scotland. J. Geol. Soc. London, 141:193-214.

Wildner W., Nardi. L.V.S., Lima E.F. 1999. Post-collisional alkaline magmatism on the Taquarembó Plateau: a well preserved Neoproterozoic-Cambrian plutono-volcanic association in southern Brazil. Intern. Geol. Rev., 41:1082-1098.

Contribution IGC-187 Received March 3, 2000
Accepted for publication May 15, 2000 